\title{
IMPLEMENTASI KEADILAN RESTORATIF DALAM SISTEM PERADILAN PIDANA SEBAGAI PERWUJUDAN NILAI-NILAI YANG BERWAWASAN PANCASILA
}

\author{
Duwi Aryadi \\ Program Pascasarjana Fakultas Hukum Universitas Diponegoro
}

\begin{abstract}
This study uses the type of doctrinal legal research combined with the concept approach analytical (analytical approach), case (case approach), and legislation (statute approach) in solving problems. The research data involved in this writing are primary legal materials in the form of previous research results, literature, related documents and legal opinions (doctrine), which are then followed by secondary legal material as important data analysis of some positive regulations and tertiary legal materials as a support in this study. The results of this study conclude that by carrying out a settlement through the practice of Restorative Justice provides an offer through an integrated approach between the perpetrator and the victim to find various solutions or the best solution between the two parties. The improvement referred to in this case will emphasize making compensation made by the perpetrators and making reparations and repairs to victims. In this case, the settlement process is following the principles of Pancasila insight by making efforts to resolve by deliberation and consensus. Restorative justice must be able to be a force to support the rule of law in the context of national development. In this case through the restorative justice approach as the embodiment of Pancasila values.
\end{abstract}

Keywords:

Restorative Justice, Criminal Justice System, Pancasila Values

\begin{abstract}
Abstrak
Penelitian ini menggunakan jenis penelitian hukum doktrinal yang dipadukan dengan pendekatan konsep (concept approach), analitis (analitycal approach), kasus (case approach) dan perundangundangan (statute approach) dalam pemecahan permasalahan. Data penelitian yang terlibat dalam penulisan ini adalah bahan hukum primer berupa hasil penelitian sebelumnya, literatur, dokumen terkait dan pendapat hukum (doktrin), yang kemudian dilanjutkan bahan hukum sekunder sebagai data analisis penting dari beberapa peraturan positif serta bahan hukum tersier sebagai penunjang dalam penelitian ini. Adapun hasil penelitian ini menyimpulkan bahwa dengan melakukan penyelesaian melalui praktik Restoratif Justice
\end{abstract}


memberikan tawaran melalui pendekatan secara integral antara pelaku dengan korban untuk mencari berbagai solusi atau jalan keluar yang terbaik diantara kedua belah pihak. Perbaikan yang dimaksud dalam hal ini akan menekankan dengan melakukan penggantian kerugian yang diperbuat oleh pihak pelaku serta melakukan pemulihan dan perbaikan pada korban. Dalam hal ini proses penyelesaianya sesuai dengan prinsip-prinsip yang berwawasan pancasila dengan melakukan upaya penyelesaian secara musyawarah dan mufakat. keadilan restoratif harus dapat dijadikan kekuatan guna mendukung supremasi hukum dalam rangka pembangunan nasional. Dalam hal ini melalui pendekatan restoratif justice sebagai perwujudan nilai-nilai Pancasila.

\section{Kata Kunci:}

Keadilan Restoratif, Sistem peradilan Pidana, Nilai-Nilai Pancasila

\section{A. PENDAHULUAN}

$\mathrm{I}$ ndonesia adalah negara hukum yang berdasarkan Pancasila, dalam menata semangat hidup berbangsa dan bernegara yang berbasis pada nilai-nilai Pancasila. Negara Indonesia menempatkan hukum sebagai panglima tertinggi dengan tujuan untuk menegakan dan mengangkat harkat dan martabat manusia. Hukum merupakan sarana yang paling tepat dalam membentuk karakter serta kepribadian suatu negara, sehingga hukum dapat dikatakan sebagai alat yang sangat vital dalam mempengaruhi setiap sendi kehidupan karena itu hukum juga disebut sebagai alat pengendalian sosial. Ketetapan ini diatur didalam Pasal 1 ayat (3) UUD NRI 1945 "Negara Indonesia adalah Negara Hukum”. Negara hukum mendasarkan seluruh tindakan atau perbuatan dan pembentukan lembaga negara pada hukum dilihat dalam ketentuan aturan secara tertulis. Secara kodrati manusia adalah makhluk ciptaan tuhan yang memiliki derajat yang sama dimata tuhan yang sudah seharusnya diperlakukan sama sesuai dengan nilai-nilai luhur kemanusiaan. ${ }^{1}$

Setiap manusia sudah tentu memiliki hak asasi, yang merupakan hak dasar yang melekat pada diri manusia sejak lahir yang tidak boleh dirampas dan diganggu oleh siapapun termasuk Negara dan bahkan Negara wajib untuk melindungi setiap hak-hak warga negaranya sebagai mana amanat dari konstitusi yaitu UndangUndang Dasar Negara Republik Indonesia Tahun 1945. Penegasan terhadap nilainilai berwawasan Pancasila di Indonesia seharusnya dilakukan dalam setiap tahapan-tahapan, baik itu pada tahapan legislasi dalam hal ini pembuatan peraturan perundang - undangan, tahap aplikasi/implementasi (penegakan hukum yang dilakukan oleh aparat penegak hukum seperti diatur dalam sistem peradilan pidana mulai dari penyidikan, penuntutan ,putusan di pengadilan, hingga dalam

\footnotetext{
${ }^{1}$ Muladi, Hak Asasi Manusia (Hakekat, Konsep dan implikasinya dalam perspektif hukum dan masyarakat), Bandung : PT. Refika Aditama, 2009, hlm.3
} 
pelaksanaan eksekusi dilembaga pemasyarakatan. ${ }^{2}$ Berhasil atau tidaknya suatu peraturan perundang-undangan yang dibuat tidak dapat dipisah lepaskan pada penerapan dan penegakan hukumnya. Dalam hal ini yang berperan penting yaitu aparat penegakan hukum (Kepolisian, Kejaksaan, Hakim, Lembaga Pemasyarakatan). Jika penegakan hukum tidak berjalan baik maka sebagus apapun Produk undang-undang yang dibuat tidak akan mencapai tujuan serta substansi arti yang sesungguhnya. Begitupun sebaliknya, sejelek apapun suatu peraturan perundang-undangan yang dibuat, jika penegak hukum nya berjalan dengan baik maka tentu keadilan dan kemanfaatan hukum akan tercapai dengan baik.

Konsep penegakan Hukum, mengadopsi teori dari Lawrence M. Friedman bahwa efektif serta berhasil tidaknya suatu proses penegakan hukum tergantung tiga unsur sistem hukum, yakni struktur hukum (struktur of law), substansi hukum (substance of the law) dan budaya hukum (legal culture). Struktur hukum menyangkut aparat penegak hukum, substansi hukum meliputi perangkat perundang-undangan dan budaya hukum merupakan hukum yang hidup (living law) yang dianut dalam suatu masyarakat. ${ }^{3}$ Struktur hukum dalam teori L. Frieman diaplikasikan sebagai Aparatur penegak hukum, merupakan penggerak dalam hal ini yaitu yang menjalankan peraturan perundang-undangan. ${ }^{4}$

Mengkritis Penegakan hukum dalam pelaksanaan hukum di Indonesia begitu banyak kekurangan dan kelemahan, Kekurangan yang paling utama untuk dinilai bukan terletak pada sistem hukum dan produk hukumnya, akan tetapi pada proses penegakan hukum. Sehingga keinginan masyarakat untuk memperoleh jaminan serta kepastian hukum masih sangat terbatas. Tentu dalam hal ini memberikan stigma negatif terhadap penegakan hukum dalam masyarakat, Penegakan dan pelaksanaan hukum belum berjalan sesuai dengan prinsip-prinsip keadilan dan kebenaran. Jika hal ini tidak dilakukan perubahan sudah tentu penegakan hukum jauh sekali dari nilai-nilai leluhur bangsa kita yakni penegakan hukum yang berwawasan nilai-nilai pancasila.

Proses penyelesaian Perkara Pidana pada umumnya diselesaikan melalui sistem peradilan pidana yang disebut sebagai Criminal Justice System. Istilah Criminal Justice System atau Sistem Peradilan Pidana (SPP) Menampakkan suatu proses mekanisme kinerja didalam penanggulangan kejahatan menggunakan dasar "pendekatan sistem". Sistem Peradilan Pidana (SPP), suatu proses yang dimulai dari tingkat penyidikan di kepolisian, dakwaan oleh jaksa, putusan oleh hakim dalam Proses Peradilan yang berakhir di lembaga pemasyarakatan. ${ }^{5}$ Criminal Justice System

\footnotetext{
${ }^{2}$ Yusriando, 2015, Implementasi Mediasi penal sebagai perwujudan nilai-nilai pancasila guna mendukung supremasi hukum dalam rangka pembangunan nasional, (Jurnal pembaharuan hukum : 2015), Vol.II, No. 1.

${ }^{3}$ W. Friedmann, the State and The Rule of Law in Mix Economy, (London: Steven \& Son, 1971), hlm. 5-6.

${ }^{4}$ Bagir Manan, Pembinaan Hukum Nasional, disampaikan untuk kuliah umum di Fakultas Hukum Universitas Padjadjaran, Bandung, 18 Agustus 1997, hlm, 8

${ }^{5}$ Romli Atmasasmita dalam Yesmil Anwar dan Adang, Sistem Peradilan Pidana ; Konsep Komponen \& Pelaksanaanya dalam penegakan hukum di Indonesia, Bandung: widya Padjajaran, Tahun 2009, hlm 33.
} 
(CJS) di Indonesia, pengaturanya terdapat didalam Kitab Undang-Undang Hukum Acara Pidana (KUHAP).

Sistem peradilan pidana terpadu sering juga disebut dengan istilah integrated criminal justice system dalam hal ini prof muladi mengemukakan pendapat didalam bukunya bahwa pemaknaan tersebut merupakan suatu sinkronisasi atau kesesuaian dan keselarasan, yang pertama dalam sinkronisasi struktural (structural syncronization) yang merupakan kesesuaian dan keselarasan dalam rangka berkaitan antar lembaga penegak hukum; yang kedua sinkronisasi substansial (substansial syncronization) yaitu kesesuaian atau keselarasan yang bersifat vertikal dan horizontal dalam hal ini yang berkaitan dengan hukum positif; ketiga yaitu Sinkronisasi kultural (cultural syncronization), yang berkesesuaian dalam menjiwai terhadap pendangan-pandangan maupun sikap-sikap falsafah secara menyeluruh yang mendasari jalanya sistem peradilan pidana. ${ }^{6}$

Dewasa ini diberbagai negara termasuk Indonesia muncul adanya ketidakpuasan dan frustasi terhadap eksistensi hukum pidana formal melalui model Criminal Justice System (CJS). Hal ini dikarenakan perubahan sekaligus perkembangan sistem peradilan pidana yang dianggap tidak lagi dapat memberikan Protection terhadap hak-hak dasar yang melekat pada diri manusia serta transparansi terhadap kepentingan secara umum. Sehingga melalui problem tersebut muncullah suatu gagasan baru dalam mengatasi kelemahan-kelemahan ataupun kekurangan yang terdapat dalam model sistem peradilan pidana melalui pengalihan yang dilakukan secara formal ke Non Formal dalam penyelesaianya, penyelesaian tersebut yaitu melalui model Restoratif Justice.

Konsep Keadilan Restoratif pada dasarnya dilakukan melalui kebijaksanaan dan pengalihan, yaitu pemindahan proses pidana ke luar proses formal untuk diselesaikan dengan musyawarah. Penyelesaian melalui konsultasi bukanlah hal baru bagi Indonesia, bahkan hukum adat di Indonesia tidak membedakan antara penyelesaian kasus pidana dan perdata, semua kasus dapat diselesaikan dengan musyawarah dengan tujuan untuk mendapatkan keseimbangan atau pemulihan keadaan. Dalam hal ini keadilan yang hendak dicapai atau dicita-citakan merupakan hasil gagasan maupun nilai-nilai leluhur suatu bangsa yang terkandung didalam falsafah Pancasila.

Penelitian ini diharapkan mampu memberikan masukan serta kontribusi terhadap pembaca maupun seluruh aparat penegak hukum dalam proses penyelesaian tindak pidana tidak melulu hanya mengenakan atau menerapkan model sistem peradilan pidana (Criminal Justice System) yang hanya akan mencapai kepastian hukum semata, sehingga mengesampingkan tujuan keadilan dan kemanfaatan hukum. Dengan demikian melalui penyelesaian pendekatan model restoratif justice dalam setiap tahapan diharapkan mampu mengakomodir seluruh aspek kepentingan pelaku dan korban tentunya dalam hal ini mencari solusi yang

\footnotetext{
${ }^{6}$ Muladi, 1996, Kapita Selekta Sistem Peradilan Pidana, Semarang: Badan Penerbit UNDIP, hlm.2.
} 
terbaik melalui jalur musyawarah untuk mencapai keadilan yang sesungguhnya yang sesuai dan sejalan dengan falsafah dan nilai-nilai yang terkandung didalam Pancasila sebagai sumber dari segala sumber hukum.

\section{B. METODE PENELITIAN}

Metode yang digunakan dalam penelitian ini berupa doktrinal yang dipadukan dengan pendekatan konsep (concept approach), analitis (analitycal approach), kasus (case approach) dan perundang-undangan (statute approach) untuk pemecahan permasalahan. ${ }^{7}$ Bentuk spesifikasi penelitian berupa kerangka perspektif analitis seputar pembaharuan yang dikutip dari peneliti-peneliti sebelumnya.

Data penelitian yang terlibat dalam penulisan ini adalah bahan hukum primer berupa hasil penelitian sebelumnya, literatur, dokumen terkait dan pendapat hukum (doktrin), yang kemudian dilanjutkan bahan hukum sekunder sebagai data analisis penting dari beberapa peraturan positif serta bahan hukum tersier sebagai penunjang dalam penelitian ini. ${ }^{8}$

\section{HASIL DAN PEMBAHASAN}

\section{Praktik Pendekatan Keadilan Restoratif Sebagai Perwujudan Nilai-Nilai Yang Berwawasan Pancasila}

Model pendekatan Keadilan Restoratif muncul didasarkan atas ide-ide yang mengkritisi bahwa penegakan hukum melalui sistem peradilan pidana dengan pemenjaraan dianggap sudah tidak efektif lagi didalam menyelesaikan persoalanpersoalan yang terjadi didalam masyarakat. Keadilan Restoratif ini sebagai upaya alternatif didalam sistem peradilan pidana tentunya dalam hal ini akan memberikan tawaran melalui pendekatan secara integral antara pelaku dengan korban untuk mencari berbagai solusi atau jalan keluar yang terbaik diantara kedua belah pihak. ${ }^{9}$ Perbaikan yang dimaksud dalam hal ini akan menekankan dengan melakukan penggantian kerugian yang diperbuat oleh pihak pelaku. ${ }^{10} \mathrm{Hal}$ ini senada dengan apa yang dikemukakan oleh John Braithwaite, ia mengatakan bahwa tujuan utama dari Restoratif Justice adalah perbaikan yang diperbuat oleh pelaku serta dalam hal ini tidak pula mengesampingkan hak-hak dari korban sebagai pihak yang dirugikan melalui konsiliasi dan rekonsiliasi dikalangan pelaku, korban dan masyarakat.Alternatif penyelesaianya dalam hal ini lebih memfokuskan kepada perdamaian antara korban dan pelaku yang sifatnya win-win solution dan pada

\footnotetext{
${ }^{7}$ Hari Sutra Disemadi dan Paramita Prananingtyas, "Kebijakan Corporate Social Responsibility (CSR) Sebagai Strategi Hukum Dalam Pemberdayaan Masyarakat Di Indonesia," (Wawasan Yuridika,2020) , 4, no. 1, pp. $1-16$

${ }^{8}$ Peter Mahmud Marzuki, Penelitian Hukum (Surabaya : Kencana, 2005).hlm.25

${ }^{9}$ Prayitno, K. P. 2012. Restorative Justice untuk Peradilan di Indonesia (Perspektif Yuridis Filosofis dalam Penegakan Hukum in Concreto). Jurnal Dinamika Hukum, Vol. 12, No.3, hlm 409

${ }^{10}$ Nurwianti, A., Gunarto \& Wahyuningsih, 2017, Implementasi Restoratif/Restorative Justicedalam Penyelesaian Tindak Pidana Kecelakaan Lalu Lintas yang Dilakukan oleh anak di Polres Rembang.Jurnal Hukum Khaira Ummah, Vol.12, No.4, hlm. 709
} 
akhirnya tentu akan memberikan keadilan substantif bukan hanya hukum yang berkutat di teks semata. Law Enforcement melalui Criminal justice System hanyalah mengutamakan aspek kepastian hukum semata tanpa memandang aspek keadilan serta kemanfaatan untuk masyarakat. Padahal penegakan hukum yang hanya berpatokan pada Undang-Undang dalam hal ini yang dicapai hanyalah kepastian hukum justru akan mengakibatkan hukum itu kehilangan makna (meaning) yang sesungguhnya, dalam hal ini tujuan hukum yang sebenarnya yaitu hukum yang memberikan rasa kebahagiaan, kemanfaatan dan keadilan bagi masyarakat guna menjamin terpenuhinya hak asasi Manusia. ${ }^{11}$

Dalam konteks Indonesia, pola-pola pendekatan restorative justice untuk menyelesaikan perkara pidana pada dasarnya telah dipraktekkan di berbagai masyarakat tradisional (masyarakat adat) Indonesia. Masyarakat adat menempuh musyawarah untuk mencapai mufakat yang merupakan nilai terpenting dari restorative justice untuk menyelesaikan permasalahan yang timbul. Konsep restorative justice sebenarnya telah mengakar dalam kehidupan dan budaya masyarakat Indonesia yang merupakan jiwa dan kepribadian (volkgeist) dari masyarakat Indonesia. Akan tetapi, pada saat penjajahan Belanda, hukum adat Indonesia disubordinasikan dengan hukum Eropa (Belanda). Setelah Indonesia merdeka, eksistensi masyarakat hukum adat telah diakui secara tersirat didalam Alinea IV Pembukaan UUD 1945, yaitu : "melindungi segenap bangsa Indonesia" yang mengandung makna bahwa negara wajib melindungi segenap bangsa Indonesia, termasuk hukum adat yang merupakan hukum asli bangsa Indonesia yang merupakan jiwa dan kepribadian (volkgeist) dari masyarakat Indonesia yang telah ada, tumbuh dan berkembang merupakan sebagai perwujudan nilai-nilai yang tercermin dalam pancasila. Kesadaran akan arti penting konsep restorative justice sebagai jiwa dan kepribadian (volkgeist) dari masyarakat Indonesia telah membuat pemerintah untuk membuat terobosan-terobosan hukum, meskipun terobosan-terobosan hukum tersebut masih bersifat parsial.

Hukum pidana Indonesia (Wvs) yang diberlakukan hingga massa sekarang ini merupakan warisan dari Negara Belanda,yang memberlakukan asas legalitas dengan sangat ketat, sehingga pola-pola penyelesaian perkara pidana dengan musyawarah mufakat tidak dikenal dalam hukum pidana Indonesia. Dalam hal ini yaitu melalui pengalihan dengan Konsep restorative justice yang menawarkan mekanisme dengan mengutamakan konsep perdamaian melalui proses musyawarah baik itu secara mediasi, rekonsiliasi dalam penyelesaian perkara dengan melibatkan partisipasi secara langsung baik korban, pelaku dan masayrakat. Hal ini berbanding terbalik dengan model pendekatan melalui sistem peradilan pidana (Criminal Justice system) sehingga praktek dalam penegakan hukum di

${ }^{11}$ Yohanes Suhardin, Fenomena Mengabaikan Keadilan Dalam Penegakan Hukum, Jurnal Mimbar Hukum, Vol. 21 No. 2, 2009, hlm. 342. 
Indonesia masih banyak menyisakan berbagai persoalan. ${ }^{12}$

Restorative justice dalam Kitab hukum pidana (Wvs) belum diatur, akan tetapi terdapat didalam Undang-Undang Nomor 11 Tahun 2012 tentang Sistem Peradilan Pidana Anak(SPPA). KUHP sebagai general rule hukum pidana materiil dan KUHAP sebagai general rule hukum pidana formil belum mengatur tentang pendekatan restorative justice dalam penegakan hukum pidana, baik di tingkat penyidikan, penuntutan maupun peradilan.

Peran bergerak dari tahap investigasi ke tahap pengawasan setelah menjalani hukuman mereka. Namun demikian, semangat yang terkandung dalam UU No. 11 Tahun 2012 tentang Sistem Peradilan Anak adalah untuk mempromosikan upaya bantuan yang adil (Restorative Justice) dan mencegah anak-anak dari proses peradilan (pengalihan). Oleh karena itu, Pasal 7 (1) menyatakan bahwa di tingkat investigasi, penuntutan, dan investigasi kasus anak-anak di pengadilan distrik harus dicari pengalihan. Tapi tidak semua pelanggaran bisa diselesaikan dengan pengalihan. Pengalihan diterapkan dalam kasus pelanggaran pidana yang dilakukan untuk penjara di bawah tujuh (7) tahun dan bukan merupakan pengulangan tindakan kriminal. Sementara itu, jika kasus anak-anak harus dimasukkan dalam proses peradilan, undang-undang memiliki kewajiban untuk memberikan bantuan kepada anak-anak di setiap tingkat pemeriksaan. Pasal 23 ayat (1) menyatakan: "Di setiap tingkat pemeriksaan anak harus diberikan bantuan hukum dan dibimbing oleh warga negara atau pendamping lain sesuai dengan ketentuan perundangundangan".

Terdapat banyak kasus yang menunjukan ketidakadilan dalam proses penyelesaian perkara melalui proses peradilan yang diimplementasikan secara sistem mulai dari tingkat penyidikan dikepolisian sampai proses pelaksanaan atau eksekusi yang dilaksanakan lembaga pemasyarakatan. Sebagai contoh terdapat Kisah yang mengusik rasa keadilan yang menimpa Mbok Minah yang berusia 55 tahun. Nenek minah yang berasal dari desa Darma Kradenan, Kecamatan Ajibarang, Kabupaten Banyumas ia harus menjalani masa tahanan rumah selama tiga bulan karena ia dituduh mencuri tiga buah kakao ditempatnya bekerja di PT. Rumpun Sari Antan 4 di Desa Darma Kradenan tak jauh dari rumahnya. Kisah ini terjadi pada tahun 2009 berawal ketika mbok Minah mengambil tiga buah Kakao yang terjatuh ditanah untuk dibawa pulang dan dijadikan benih. Tiga biji kakao tersebut diletakkan ditanah, sementara si mbok Minah melanjutkan pekerjaanya membersihkan ilalang dikebun kakao milik perusahaan tersebut. Kemudian berpapasan secara tidak sengaja pula mandor kebun tersebut lewat dan ia melihat tiga buah kakao yang diletakkan oleh mbok Minah tadi. Lalu simandor tersebut mencari orang yang dianggap mencuri buah kakao tersebut. Kemudian terdengar lah oleh mbok Minah tersebut ia mengakui bahwa tiga buah kakao tersebut ia yang

${ }^{12}$ Kristian \& Tanuwijaya, C. (2015). Penyelesaian Perkara Pidana dengan Konsep Keadilan Restoratif (RestorativeJustice) dalam Sistem Peradilan Pidana Terpadu di Indonesia. Jurnal Hukum Mimbar Justitia, Vol.1, No.2, hlm.597-598 
ambil karena buah tersebut jatuh dari pohonya. Kemudian mbok Minah dibawa kekantor Polisi oleh simandor tersebut dengan tuduhan bahwa mbok Minah sudah mencuri buah kakao milik perusahaannya. Kasus ini kemudian bergulir hingga kepengadilan. Kemudian mbok Minah dijatuhi dengan hukuman tiga bulan tahanan rumah.

Jika kita cermati terhadap kasus yang menimpa mbok Minah diatas dengan menyikapi tindakan yang salah bukanlah hanya dengan semata-mata menghukum pelaku, tetapi kita juga harus melihat dari perspektif yang lebih luas. Maka seharusnya kasus kecil seperti diatas cukuplah penyelesaianya melalui musyawarah. Maka menyelesaikan sebuah tindakan kejahatan harus dilakukan dengan melibatkan tiga belah pihak yaitu korban, pelaku dan masyarakat. Pertemuan musyawarah dan lingkaran (circles) yang diterapkan dalam pendekatan restoratif memenuhi kebutuhan pokok manusia. Setiap orang memiliki kebutuhan pokok untuk didengarkan dan dihormati. Maka melalui pertemuan, musyawarah, dan lingkaran memiliki yang memfasilitasi korban dan pelaku untuk berdialog memuaskan kebutuhan dasar tersbut. Didalam berdialog, korban dapat menyampaikan pengalaman penderitaan yang disebabkan oleh pelaku kejahatan. Dipihak lain, pelaku secara empatik mendengarkan dan menerima sharing pengalaman dari korban. Pelaku juga mengakui kesalahan yang telah dilakukan, dan selanjutnya dia dapat menyampaikan permintaan maaf dan penyesalanya. Kemudian korban dapat memberikan maaf dan memberi persetujuan terhadap kompensasi atas penderitaan yang dideritanya. Musyawarah berakhir ketika perdamaian dan rekonsiliasi terjadi, dan sejumlah kompensasi disetujui oleh dua pihak. Demikianlah keadilan restoratif terwujud ketika perdamaian dan rekonsiliasi antara korban, pelaku, dan masyarakat terwujud atau dipulihkan.

Di negara-negara yang sistem hukum dan peradilanya belum dapat berjalan secara adil, praktik keadilan restoratif semestinya lebih tepat untuk diterapkan dari pada retributif. Keadilan restoratif dapat menjamin kesejahteraan sosial, karena ia berakhir dengan perdamaian dan rekonsiliasi, bukanya hukuman dan balas dendam. Proses peradilan yang tidak dapat memutuskan hukuman secara adil justru akan menyulut kebencian diantara korban dan pelaku, bahkan ia dapat merangsang timbulnya pembalasan yang brutal. Keadilan restoratif juga akan menghilangkan arogansi orang-orang kaya dan memiliki kekuasaan. Dalam banyak kasus, orangorang kaya dan memiliki kekuasaan secara congkak membawa keproses pengadilan kasus-kasus yang sangat sepele karena mereka mampu membayar biaya untuk proses pengadilan. Sebagaimana contoh kasus Mbok Minah diatas. Keadilan restoratotif harus dipromosikan untuk mengubah arogansi dan kesombongan menjadi kerendahan hati dan kesabaran.

Berbanding terbalik dengan kasus mbok minah diatas, kasus yang baru-baru ini viral didunia maya maupun media massa atas tindakan terpuji seorang polisi yang tidak mau melanjutkan proses pemeriksaan anak yang melaporkan ibu kandungnya. 
Kasus ini ${ }^{13}$ bermula pada saat sang anak inisial $\mathrm{M}$ menjual tanah warisan milik ayahnya senilai Rp 200 juta. Dari hasil penjualan warisan tersebut, sang ibu hanya mendapatkan bagian senilai Rp 15 juta. Kemudian uang tersebut oleh sang ibu dibelikan satu unit sepeda motor. Kemudian karena alasan ada saudara yang ingin meminjamnya, sepeda motor tersebut kemudian ditinggalkan dirumah saudara tersebut. Mengetahui hal tersebut, ternyata membuat sang anak (M) keberatan dan kemudian menuduh sang ibu melakukan penggelapan sepeda motor. Pada saat itulah sang anak melaporkan ibu kandungnya ke Polres Lombok Tengah, yang kemudian oleh Kasat Reskrim Polres Lombok Tengah AKP Priyo Suhartono tidak menerima laporan tersebut dan merasa prihatin terhadap kasus yang ingin menjebloskan ibu kandungnya kepenjara. AKP Priyono meminta anak tersebut agar penyelesaian kasusnya cukup melalui musyawarah keluarga. Bahkan diketahui aksi polisi tersebut mengganti uang yang diminta oleh sang anak.

Dalam kasus tersebut Kasat Reskrim Polres Lombok Tengah AKP Priyo Suhartono dengan tidak menerima laporan sang anak menurut hemat penulis sudah menunjukan bahwa tidak semua kasus yang diselesaikan melalui proses penyelesaian secara formal memberikan keadilan dan kemanfaatan hukum. Sehingga sikap progresif seperti inilah yang patut diteladani oleh seluruh aparat penegak hukum melalui keadilan restoratif. Keadilan restoratif akan melatih dan mengajar orang untuk dengan mudah memaafkan mereka yang bersalah dan melakukan kekerasan, karena melalui dialog keadilan restoratif akan mendorong orang untuk menyadari bahwa dirinya juga sering melakukan kesalahan-kesalahan dan kekerasan pada orang lain. Kesediaan untuk berdialog dalam pertemuan dan musyawarah adalah manifestasi dari kerendahan hati dan kesabaran. Hal ini perlu dilatihkan terus menerus. Maka kekasaran yang tampak dalam pelbagai demonstrasi melakukan pengrusakan fasilitas umum dapat diperlunak melalui pelbagai berdialog yang terjadi dalam pendekatan restoratif. Dalam hal inilah keadilan restoratif harus dipromosikan untuk dapat ditegakkan di seluruh lapisan masyarakat .${ }^{14}$

\section{Prinsip-prinsip dalam Pendekatan Keadilan Restoratif}

Dalam prakteknya masing-masing aparat penegak hukum dapat melakukan kebijakan-kebijakan yang bersifat internal. Sebagai ujung tombak penegakan hukum pidana, sekaligus sebagai "penegak hukum jalanan",masyarakat merasakan adil atau tidak adil penegakan hukum tersebut diawali dari proses yang dilakukan oleh polri. Oleh karenanya, sangat urgen bagi polri untuk menerapkan restorative justice dalam penyidikan perkara-perkara yang ditanganinya agar keadilan bisa dirasakan lebih awal yang pada akhirnya akan makin menumbuhkan kepercayaan dari masyarakat, sehingga lebih mudah mewujudkan keamanan dan ketertiban dalam masyarakat. Adapun Prinsip-prinsip keadilan restoratif yang

\footnotetext{
${ }^{13}$ Kompas.com pada tanggal 29 Juni 2020.

${ }^{14}$ Yoachim Agus Tridiatno,(2015), Keadilan Restoratif, Cahaya Atma Pustaka :Yogyakarta, hlm.51-52
} 
ditawarkan oleh susan sharpe :

1. Keadilan restoratif mengandung partisipasi penuh dan konsensus ( Restoratif justice invites full participation and konsensus). Dalam hal ini dimaksudkan bahwa antara korban dan pelaku dilibatkan secara langsung dan aktif. Selain itu juga membuka peluang dan kesempatan bagi orang lain atau pihak ketiga yang apabila terdapat kerugian serta merasa terganggu akibat efek perbuatan dari pelaku.

2. Keadilan restoratif berusaha menyembuhkan kerusakan/kerugian yang ada akibat terjadinya tindakan kejahatan (Restoratif justice seeks to heat what is broken). Disinilah kelebihan dari pada penyelesaian melalui pendekatan restoratif justice hal ini diibaratkan seorang dokter yang memberikan diagnosa kepada pasienya sesuai dengan apa yang pasien derita sehingga obat yang diberikan kepada pasien tersebut tentu akan bereaksi dengan apa yang ia derita dan pada akhirnya sipasien tersebut dapat sembuh kembali dalam hal ini restoratif justice merupakan obat yang tepat dalam pemulihan korban. Selain korban, pelaku juga butuh penyembuhan dalam hal ini pelaku juga butuh untuk dibebaskan dari kebersalahan dan ketakutannya. Dengan demikian model pendekatan restoratif justice sangat berperan penting untuk pemulihan keadaan para pelaku dan korban.

3. Keadilan restoratif memberikan pertanggungjawaban langsung dari pelaku secara utuh (Restoratif Justice seeks to full and direct accountability). Hal ini bermakna bahwa dalam model penyelesaian melalui pendekatan restoratif justice ini, pelaku harus mampu menunjukan fakta pengakuanya. Dalam hal ini Pengakuanpelakusecara langsung dalam mempertanggungjawabkan kesalahan yang diperbuat serta memperbaiki dirinya untuk tidak mengulangi perbuatan tersebut.

4. Keadilan restoratif menyatukan kembali kepada warga masyarakat yang telah terpisah atau terpecah karena tindakan kriminal (Restoratif Justice seeks to recinite what has been devide). Proses penyelesaian melalui pendekatan restoratif justice berusaha untuk menyatukan kembali pemulihan yang dilakukan oleh pelaku akibat tindakan kriminal yang diperbuatnya sehingga memunculkan stigma negatif dari masyarakat. Upaya tersebut dengan melakukan rekonsiliasi antara korban dengan pelaku dan mengintergrasikan keduanya kembali kedalam masyarakat sehingga label "korban" dan "pelaku" tidak akan melekat selamanya karena baik dari pihak korban dan pelaku pada dasarnya masing-masing mempunyai hak untuk mencapai masa depannya.

5. Keadilan restoratif memberikan ketahanan kepada masyarakat agar dapat mencegah agar terjadinya tindakan kriminal berikutnya ( Restoratif justice seeks to strenghen the community in order to prevent further harms). Tindakan kriminal tidak dapat dipugkiri, bahwa kapanpun dan dimanapun tindakan-tindakan yang melawan hukum akan senantiasa terjadi hal ini disebabkan berbagai faktor, baik itu faktor ekonomi, faktor keadilan yang tidak dapat ditegakkan secara baik. Dengan demikian, korban dan pelaku harus kembali ditempatkan untuk 
menjaga keutuhan masyarakat dan membuat tempat yang adil dan aman untuk kelangsungan hidup.

6. Proses penyelesaian melalui pendekatan restoratif memfokuskan perhatian terhadap pemulihan dan perdamaian kembali korban, pelaku kejahatan, dan masyarakat. Berbeda dengan proses peradilan yang hanya melibatkan para petugas dilembaga peradilan seperti hakim, jaksa serta pelaku kejahatan dan pembelanya. Adapun Keadilan restoratif meminimalisasi peran pemerintah.

Howard Zehr menegaskan dengan beberapa prinsip-prinsip keadilan restoratif yaitu sebagai berikut : ${ }^{15}$

1. Keadilan restoratif bukanlah pertama-tama berarti memaafkan dan rekonsiliasi, maksudnya adalah banyak pihak yang mengatakan termasuk pihak korban curiga bahwa keadilan restoratif adalah bentuk pemaksaan pada korban untuk memaafkan dan berdamai dengan pelaku tindak kejahatan. Dalam hal ini bahwa keadilan restoratif tidaklah fokus hanya pada permaafan dan rekonsliasi. Akan tetapi tidak menutup kemungkinan pula bahwa keadilan restoratif terjadi akan berdampak dari program restoratif adalah permaafan dan rekonsiliasi.

2. Keadilan restoratif bukan sekedar mediasi. Dalam hal ini memang, pendekatan restoratif justice mengutamakan terjadinya pertemuan, namun bukan sematamata hanya bertujuan membuat mediasi. Cikal- bakal keadilan restoratif merupakan program mediasi seperti VORP, VOM, FGC, dan lingkaran peradilan. Namun selanjutnya istilah yang dipakai adalah konferensi, dialog, atau musyawarah. Pendekatan melalui restoratif justice tidak akan pernah tercapai apabila pertemuan antara para korban dan pelaku tidak dilakukan.

3. Keadilan restoratif bukanlah dimaksudkan untuk memberikan efek jera agar pelaku tidak mengulangi lagi kejahatan yang diperbuat. Maka apabila setelah model pendekatan restoratif justice diterapkan, pelaku mengulangi bperbuatanya lagi, itu bukan berarti kegagalan model pendekatan restoratif justice. Yang paling penting dalam model pendekatan restoratif justice adalah kebutuhan para pihak baik itu korban, pelaku dan masyarakat.

4. Keadilan restoratif justice bukan program siap pakai, program-program restoratif justice haruslah dibangun dari bawah sesuai dengan keadaan dan kebutuhan masyarakat. Inisiatif dari masyarakat sangat dibutuhkan dalam program-program keadilan restoratif dengan tetap beregang dengan prinsipprinsip dalam keadilan restoratif.

5. Keadilan restoratif tidak hanya dapat diterapkan pada kasus-kasus kecil atau kasus-kasus baru. Keadilan restoratif justice dapat diterapkan pada kasus apa saja, baik itu kasus besar atau kecil, kasus anak-anak maupun orang dewasa.

6. Keadilan restoratif bukan dimaksudkan untuk menggantikan sistem hukum. Keadilan restoratif bukanlah untuk mengganti pemenjaraan dan retribusi. Keadilan restoratif menekankan pemulihan kerusakan dan keretakan yang

${ }^{15}$ Ibid, hlm. 39-40 
diakibatkan oleh karena tindak kejahatan. Pendekatan retributif dan legal hanya memandang dari dimensi publik dan kemasyarakatan, dan kurang melihat dimensi lokal dan personal sehingga dan penangananya diserahkan pada negara. Pendekatan restoratif membuat seimbang dengan memperhatikan dimensi lokal dan privat.

7. Prinsip dasar dari keadilan restoratif yaitu mengutamakan pemulihan atau restorasi dari semua pihak yang terkena dampak dari tindak kejahatan, baik itu korban, pelaku serta masyarakat. Korban adalah pihak pertama yang paling dirugikan oleh para pelaku kejahatan. Berkaitan keadilan restoratif yang mengutamakan pemulihan pada tiga pihak, Tentu dalam hal ini tidak dapat dipenuhi oleh proses peradilan. Dalam proses peradilan korban tindak kejahatan diabaikan, karena tindak kejahatan dipahami sebagai perbuatan yang melawan atau merugikan Negara. Dalam hal ini peranan korban diambil alih oleh negara. Negaralah yang mempunyai tanggung jawab untuk menghukum pelaku, sementara itu korban tindak kejahatan tidak mendapatkan hak apa-apa. Artinya dalam hal ini Negara melalui penegakan hukum tidak dapat memberikan pemulihan pihak korban yang sedang merasakan kesulitan dan penderitaan. Hukuman yang diberikan pada pelaku tindak kejahatan sama sekali tidak bersangkut pautan dengan penderitaan korban, karena dalam hal ini kebutuhan korban diabaikan. Dengan demikian disinilah kehadiran restoratif justice berada ditengah-tengah yang tidak hanya fokus pada pelaku kejahatan akan tetapi juga akan fokus pada kebutuhan korban. ${ }^{16}$

\section{Keadilan Restoratif Dimasa Yang Akan Datang}

Kebijakan Hukum Pidana dalam Pengaturan Pendekatan Restorative Justice pada Masa yang Akan Datang Sejak berdirinya Indonesia, para founding fathers telah menetapkan UUD 1945, yang menyatakan bahwa Negara Indonesia adalah negara yang berdasar atas bahwa Indonesia merupakan sebuah negara hukum. Hal itu terlihat pada Penjelasan Umum hukum (rechtsstaat) dan tidak berdasarkan kekuasaan (machtsstaat).Rechtsstaat dalam Penjelasan Umum UUD 1945 tersebut bukan konsep rechtsstaat sebagaimana yang diterapkan dalam sistem hukum civil law, melainkan hanya istilah yang dipergunakan untuk menyebutkan konsep negara hukum secara umum. Pasca amandemen, penegasan tersebut tercantum dalam Pasal 1 ayat (3) UUD NRI 1945. Penegasan tersebut menjelaskan bahwa konsep negara hukum Indonesia bukanlah konsep negara hukum rechtsstaat maupun the rule of law,melainkan gabungan dari keduanya, yaitu negara hukum yang mempunyai ciri khas Indonesia yang menjadikan nilai-nilai yang terkandung dalam Pancasila sebagai dasar kehidupan berbangsa dan bernegara, yang disebut Negara Hukum Pancasila.

Menurut I Dewa Gede Atmadja, ciri esensial Negara Hukum Pancasila adalah negara hukum yang berpangkal pada asas kekeluargaan, musyawarah mufakat 
dan perlindungan HAM dengan prinsip keseimbangan antara hak dan kewajiban serta fungsi hukum pengayoman. ${ }^{17}$ Dalam kerangka Konsep Negara Hukum Pancasila, pendekatan konsep restorative justice baru diakui secara tersirat dalam konstitusi dan baru diatur secara parsial dalam beberapa peraturan perundanganundangan hukum pidana, di antaranya dalam UU SPPA dan UU Otonomi Khusus bagi Provinsi Papua, yang telah mengakui adanya suatu cara "musyawarah mufakat" dalam penegakan hukum pidana. KUHP sebagai induk hukum materiil dan KUHAP sebagai induk hukum formil belum mengatur cara "musyawarah mufakat" yang merupakan nilai inti dari konsep restorative justice untuk menyelesaikan perkara pidana.

Dalam perspektif ius constituendum, diperlukan kebijakan/politik hukum untuk mengatur penerapan konsep restorative justice dalam penegakan hukum pidana, baik di tingkat penyidikan, penuntutan dan peradilan. Menurut Soedarto, politik hukum adalah usaha untuk mewujudkan peraturan-peraturan yang baik sesuai dengan keadaan dan situasi pada suatu saat dan kebijakan negara melalui badan-badan yang berwenang untuk menetapkan peraturan-peraturan yang dikehendaki, sehingga apa yang terkandung dalam masyarakat dapat diekspresikan oleh peraturan-peraturan tersebut dan pada akhirnya apa yang dicita-citakan akan dapat tercapai. ${ }^{18}$ Barda Nawawi Arief berpendapat bahwa penanggulangan kejahatan adalah tujuan dari usaha dan kebijakan untuk membuat peraturan hukum pidana tersebut, sehingga politik hukum pidana identik dengan pengertian "kebijakan penanggulangan kejahatan dengan hukum pidana". Usaha penanggulangan kejahatan dengan hukum pidana pada hakekatnya juga merupakan bagian dari usaha penegakan hukum, sehingga kebijakan hukum pidana merupakan bagian pula dari kebijakan penegakan hukum (law enforcement policy). Dalam arti luas, kebijakan hukum pidana mencakup kebijakan di bidang hukum pidana materiil, hukum pidana formal dan hukum pelaksanaan pidana. Selanjutnya Barda Nawawi Arief mengemukakan bahwa hakekat penanggulangan kejahatan melaluipembuatan undang-undang adalah bagian integral dari usaha perlindungan masyarakat (social welfare), sehingga politik hukum pidana juga merupakan bagian integral dari kebijakan atau politik sosial (social policy). Dengan demikian,dalam pengertian social policy juga tercakup di dalamnya social welfare policy dan social defence policy. ${ }^{19}$

Kondisi masyarakat Indonesia yang berkembang cepat seiring perkembangan dunia internasional serta kuatnya tuntutan akan keadilan dan kepastian hukum, menyebabkan beberapa masalah kejahatan tidak lagi dapat diatasi oleh KUHP dan KUHAP. Kondisi inilah yang mengakibatkan polri dalam

\footnotetext{
${ }^{17}$ Putra, I. K. C. 2017. Relevansi Konsep Negara Hukum Pancasila dengan Welfare State dalam Implementasinya dengan Pelayanan Publik di Indonesia. Jurnal Magister Hukum Udayana (Udayana Master Law Jurnal), Vol. 6, No.1, hlm.3

${ }^{18}$ Barda Nawawi Arief, 2016, Bunga Rampai Kebijakan Hukum Pidana, Jakarta : Kencana, hlm.6

${ }^{19}$ Ibid, hlm.4-5
} 
tingkat penyidikan telah mengambil langkah-langkah kebijakan dalam melakukan penegakan hukum. Polri harus tetap memperhatikan berbagai aspek kehidupan dalam masyarakat, tidak hanya berdasarkan asas legalitas semata, akan tetapi juga mempertimbangkan asas legitimasi dalam bentuk kearifan lokal dan situasional. Dalam pandangan an sich normatif, eksistensi kebijakan-kebijakan polri tersebut masih dapat dipertanyakan legitimasinya. Kebijakan-kebijakan tersebut dianggap tidak selaras dengan peraturan di atasnya seperti KUHP dan KUHAP. Bahkan Andi Hamzah berpendapat bahwa sesuai dengan Pasal 1 KUHAP Belanda, acara pidana dijalankan hanya menurut cara yang diatur oleh undangundang, sehingga acara pidana tidak boleh diatur oleh suatu peraturan yang lebih rendah dari undang-undang dalam arti formil.

Dalam perspektif ius constituendum, Konsep Negara Hukum dan Teori Kebijakan Hukum Pidana tersebut berkorelasi dengan Teori Hukum Progresif dari Satjipto Rahardjo dimana inti dari teori ini adalah bahwa hukum itu selalu dituntut progress atau maju dan berwawasan ke depan termasuk manusianya atau hukum untuk manusia bukan sebaliknya manusia untuk diperalat hukum. ${ }^{20}$ Untuk kemajuan perkembangan hukum, manusia harus memiliki terobosan dalam menciptakan substansi hukum dan mengaplikasikan hukum itu sendiri serta memiliki progress dalam mengatasi kekosongan norma,termasuk menggagas dan mewujudkan substansi hukum terkait dengan pendekatan restorative justice dalam menyelesaikan tindak pidada di tingkat penyidikan. Hukum ke depan harus menyesuaikan dengan perkembangan masyarakat. Oleh karenanya, dalam perspektif ius constituendum perlu dilakukan pembaharuan/reformulasi dalam bidang hukum pidana materiil dan pembaharuan/reformulasi dalam bidang hukum pidana formil yang sesuai dengan sistem nilai-nilai yang berwawasan pancasila sebagai cerminan mayarakat Indonesia pada umumnya.

Terdapat beberapa tahap yang harus dilewati untuk sampai pada kesediaan untuk memaafkan dan rekonsiliasi, menurut Olga Botcharova dalam gagasanya tentang lingkaran kekerasan tahapan-tahapan tersebut sebagai berikut :

1. Mengungkapkan kesedihan;

2. Menerima kehilangan/kerugian dan berani menghadapi ketakutan ;

3. Memikirkan kondisi pelaku dalam hal ini memunculkan pertanyaan mengapa mereka melakukan itu;

4. Bergerak mengatasi toleransi;

5. Memilih untuk memaafkan;

6. Menegosiasikan penyelesaian masalah;

7. Menetapkan keadilan restoratif;

8. Bergerak menuju rekonsiliasi.

\footnotetext{
${ }^{20}$ Satjipto Rahardjo, 2007, Biarkan Hukum Mengalir, Catatan Kritis tentang Pergulatan Manusia dan Hukum, Kompas, Jakarta.
} 
Namun apabila tahapan-tahapan diatas tidak dapat diproses dan dilalui dengan baik, yang terjadi adalah tindakan pembalasan yang dibenarkan (act of justified aggression). Meski demikian, menurut Botcharova dan ia meyakini bahwa di dalam jiwa manusia terdapat kebaikan-kebaikan dasar (basic goodness) yang dapat mencegah manusia dari keinginan untuk membalas dengan tindakan kekerasan. Hal ini dapat dibuktikan dengan kasus bapak Suroto dan Ibu Elisabeth Diana yang bersedia memaafkan dua orang yang membunuh anak tunggalnya. Sikap memaafkan ini ditunjukkan ketika dua remaja pembunuh itu datang langsung kerumahnya untuk melayat. sikap memaafkan seperti inilah yang seharusnya menjadi contoh kita kedepanya dalam satiap penyelesaian permasalahan maupun konflik yang terjadi ditengah masyarakat melalui musyawarah.

Seluruh proses musyawarah harus mengarah pada pemulihan hubungan antara pihak korban dan pelaku. Pihak pelaku harus mengakui, menyesali, dan bertanggung jawab atas tindakanya, serta puncaknya adalah kesediaan untuk minta maaf kepada seluruh keluarga korban. Musyawarah juga membicarakan ganti rugi dan kompensasi yang ditanggung oleh pihak pelaku. Tentu dalam hal ini tidaklah mudah menentukan besarnya ganti rugi atau kompensasi, karena berapapun besarmya ganti rugi atau kompensasi tidak akan seimbang dengan penderitaan korban. Besarnya ganti rugi dan kompensasi dalam hal ini merupakan sebagai simbol dari penyesalan dan tanggungjawab dari pelaku.

Dalam menyikapi tindak kejahatan dimasa yang akan datang paradigma tentang kejahatan dan hukuman harus diubah. Jika seseorang yang melakukan tindak pidana, bukan berarti semata-mata memikirkan hukuman bagi pelaku, tetapi pemulihan bagi korban. Fokus pada hukuman bagi pelaku hanya akan memperbesar nafsu balas dendam, sementara korban yang sungguh menderita malah diabaikan. Sebaliknya perhatian harus diarahkan pada korban. Korban harus disembuhkan fisik dan mentalnya. Korban harus mendapatkan kompensasi dari penderitaanya.Sebaliknya,pelaku tindak kejahatan harus mempertanggungjawabkan tindakanya. Pertama-tama pelaku harus mengakui tindakanya, dan menjelaskan alasan-alasan yang mendorong ia melakukan tindakan kejahatan tersebut. Kemudian pelaku harus memberikan kompensasi pada korban serta meminta maaf atas tindakanya. Dengan mempertanggungjawabkan atas perbuatanya itulah martabat pelaku sebgai manusia yang bertanggungjawab dipulihkan. Semua rangkaian tersebut dilakukan dengan konteks musyawarah dalam masyarakat, komunitas, atau paguyuban-paguyuban. Dengan demikian akan terjalin kehidupan yang harmonis baik antara korban, pelaku dan masyarakat sehingga hal ini mencerminkan kebudayaan bangsa indonesia dengan mengutamakan musyawarah mufakat dalam setiap problem yang terjadi yang sesuai dengan nilai-nilai yang berwawasan pancasila.

\section{KESIMPULAN}

Implementasi penyelesaian melalui pendekatan Restoratif Justice sebagai perwujudan nilai-nilai Pancasila yang diharapkan, berbagai dampak positif keadilan 
restoratif harus dapat dijadikan kekuatan guna mendukung supremasi hukum dalam rangka pembangunan nasional. Dalam hal ini melalui pendekatan restoratif justice sebagai perwujudan nilai-nilai Pancasila mempunyai beberapa implikasi positif. Oleh karena itu, sangat diperlukan adanya undang- undang mediasi penal. Pada undang-undang ini hendaknya diatur tentang mediasi penal yang dilakukan ditingkat penyidikan, penuntutan, pengadilan dan lembaga pemasyarakatan. Selain itu, juga diatur tentang eksistensi lembaga baru, petugas mediator, proses dan substansi mediasi penal. Misalnya, mekanisme mediasi penal pada tingkat penyidikan, antara pelaku dan korban, masuk dalam sistem peradilan pidana. Pihak kepolisian melakukan proses mediasi penal. Apabila mediasi penal berhasil, maka dibuat perdamaian, yang dapat berupa pemberian ganti rugi, rekonsiliasi, perkaranya tidak sampai ke pengadilan, atau dicabut. Apabila, mediasi penal yang dilakukan gagal, maka kembali ke dalam sistem peradilan pidana. Tentu dalam hal ini kita selalu mengharapkan keadilan restoratif dapat ditegakkan secara baik dengan melakukan Semua rangkaian dalam konteks musyawarah dalam masyarakat, komunitas, atau paguyuban-paguyuban. Dengan demikian akan terjalin kehidupan yang harmonis baik antara korban, pelaku dan masyarakat sehingga hal ini mencerminkan kebudayaan bangsa indonesia dengan mengutamakan musyawarah mufakat dalam setiap problem yang terjadi yang sesuai dengan nilainilai yang berwawasan pancasila.

\section{Daftar Pustaka}

Barda Nawawi Arief. 2016. Bunga Rampai Kebijakan Hukum Pidana, Jakarta : Kencana.

Bagir Manan. 1997. Pembinaan Hukum Nasional, Bandung.

Hari Sutra Disemadi dan Paramita Prananingtyas. 2020. Kebijakan Corporate Social Responsibility (CSR) Sebagai Strategi Hukum Dalam Pemberdayaan Masyarakat Di Indonesia, Wawasan Yuridika,Vol. 4, No. 1.

Kristian \& Tanuwijaya, C. 2015. Penyelesaian Perkara Pidana dengan Konsep Keadilan Restoratif (RestorativeJustice) dalam Sistem Peradilan Pidana Terpadu di Indonesia. Jurnal Hukum Mimbar Justitia, Vol.1, No.2.

Kompas.com pada tanggal 29 Juni 2020.

Muladi. 2009. Hak Asasi Manusia (Hakekat, Konsep dan implikasinya dalam perspektif hukum dan masyarakat), Bandung : PT. Refika Aditama.

Muladi, 1996, Kapita Selekta Sistem Peradilan Pidana, Semarang : Badan Penerbit UNDIP.

Nurwianti, A., Gunarto \& Wahyuningsih. 2017. Implementasi Restoratif/Restorative Justicedalam Penyelesaian Tindak Pidana Kecelakaan Lalu Lintas yang Dilakukan oleh anak di Polres Rembang.Jurnal Hukum Khaira Ummah, Vol.12, 
No.4.

Peter Mahmud Marzuki, 2005, Penelitian Hukum, Surabaya : Kencana.

Prayitno, K. P. 2012. Restorative Justice untuk Peradilan di Indonesia (Perspektif Yuridis Filosofis dalam Penegakan Hukum in Concreto). Jurnal Dinamika Hukum, Vol. 12, No.3.

Putra, I. K. C. 2017. Relevansi Konsep Negara Hukum Pancasila dengan Welfare State dalam Implementasinya dengan Pelayanan Publik di Indonesia. Jurnal Magister Hukum Udayana (Udayana Master Law Jurnal), Vol. 6, No.1.

Romli Atmasasmita dalam Yesmil Anwar dan Adang. 2009. Sistem Peradilan Pidana ; Konsep Komponen \& Pelaksanaanya dalam penegakan hukum di Indonesia, Bandung : widya Padjajaran.

Satjipto Rahardjo, 2007, Biarkan Hukum Mengalir, Catatan Kritis tentang Pergulatan Manusia dan Hukum, Kompas, Jakarta.

W. Friedmann. 1971. The State and The Rule of Law in Mix Economy, London: Steven \& Son.

Yohanes Suhardin, 2009. Fenomena Mengabaikan Keadilan Dalam Penegakan Hukum, Jurnal Mimbar Hukum, Vol. 21 No. 2.

Yoachim Agus Tridiatno. 2015. Keadilan Restoratif, Yogyakarta: Cahaya Atma Pustaka.

Yusriando. 2015. Implementasi Mediasi penal sebagai perwujudan nilai-nilai pancasila guna mendukung supremasi hukum dalam rangka pembangunan nasional, (Jurnal pembaharuan hukum ), Vol.II. No.1 